\title{
Petrographic Studies and Paleoenvironmental Reconstruction of Some Outcropping Sediments in Parts of Eastern Dahomey Basin, South Western, Nigeria
}

\author{
Obomighie, P.O ${ }^{1}$, Gwegwe, J.O ${ }^{1}$ and Oluwadebi A.G ${ }^{2}$ \\ ${ }^{1}$ Department of Geosciences, University of Lagos, Lagos, Nigeria. \\ ${ }^{2}$ Department of Geological Science, Osun State University, Osogbo, Nigeria
}

\begin{abstract}
The sedimentary facies outcropping some parts of the Ise Formation, Dahomey Basin as exposed in the study area have been subjected to sedimentological and petrological analyses. The study focused on deciphering the paleodepositional environment and attempting a classification of the sandstone. Field studies and laboratory analyses were carried out to determine and document the mineralogy, texture, transportation history, classification, provenance and paleodepositional environment. Results from the granulometric analysis showed that sandstones which are mainly fluvial, were deposited within alluvial, braided-streams and meandering subenvironments ranging from medium-grained to pebbly sand, poorly sorted (average 1.27Ф), with few moderately to very well sorted (average $0.96 \Phi$ to 0.29 Ф) and with skewness values that is predominantly fine skewed. Thin section petrographic results revealed quartz as the most common and abundant mineral while feldspar, mica, rock fragment, and accessory minerals were minor components, the sandstone is therefore classified as quartz arenites and wackes. The transportation history shows that the sediments of the studied area are still relatively very close to the provenance. The main cementing minerals identified in the studied sandstones include: iron oxide, quartz and clay with iron oxide dominating. The iron oxide appeared as coating on detrital grains, stain clay matrix or disseminated within the sediments. Detrital mineralogy of the analysed sandstone samples indicates that the source rock lithology is related to igneous and metamorphic origin with little or no contribution from sedimentary origin suggesting continental block setting within the cratonic interior provenances.
\end{abstract}

Keywords: Ise Formation, Sandstone, Granulometric, Provenance, Fluvial

\section{Introduction}

Sediments resulting from the weathering of pre-existing igneous, metamorphic and sedimentary rocks and formed through the processes of erosion, transportation, sorting, deposition and lithification are termed sedimentary rocks. Siliciclastic materials are usually derived by erosion of terranes outside the basin of deposition, but the source area or provenance may also include terranes within the basin. Sediment is the combined name for loose, solid particles that originate from the weathering and erosion of pre-existing rocks [1].

The study area is located within the eastern part of Dahomey Basin between latitude $6^{\circ} 40^{\prime} \mathrm{N}$ to $6^{\circ} 55^{\prime} \mathrm{N}$ and longitude $3^{\circ} 47^{\prime} \mathrm{N}$ to $4^{\circ} 19^{\prime} \mathrm{N}$ accessible by major roads (Fig 1). The analysis of the sedimentary fills in a basin provides clues to the conditions prevalent during its evolutions; the source of the sediments, depositional processes, transportation history, and prevailing environmental conditions. The research aims to study the sedimentological and petrographical attributes of the outcrop samples of Ise Sandstone Formation in order to deduce the mode of transportation and history, provenance, paleoenvironmental reconstruction and classify the sandstone.

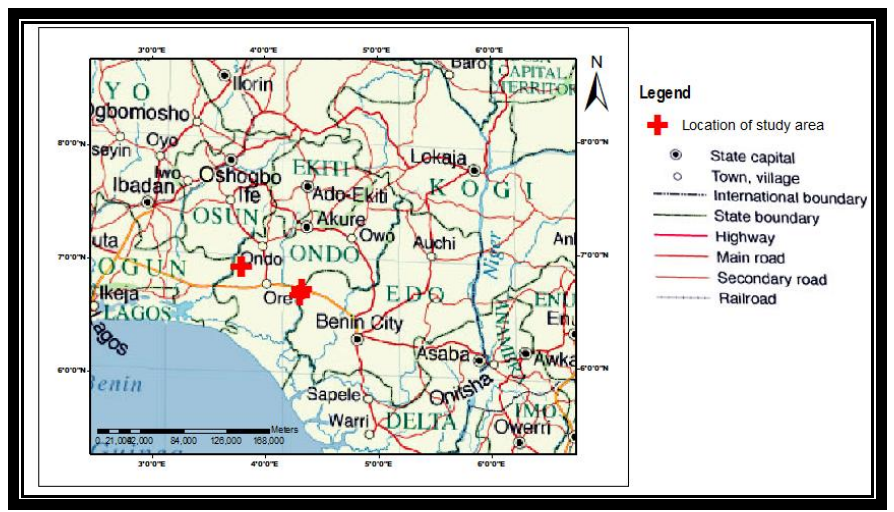

Fig 1: Map showing location of the Study Area 


\section{Regional Geological Setting}

The Dahomey Basin constitutes an integral part of the geologic history of West Africa, which evolved during Late Jurassic to Early Cretaceous at the start of the rifting and associated with the opening of the Gulf of Guinea[2]. It stretches from Volta-Delta (southeastern Ghana) through Togo and the Republic of Benin to southwestern Nigeria; the basin is separated from the Niger Delta by a subsurface basement high referred to as the Okitipupa Ridge ([3];[4];[5]) (Fig 2). The tectonic evolution of the Dahomey Basin, owes its genesis to the tectonic activities that accompanied the rifting and separation of African from South American plates, and the subsequent opening of the Atlantic Ocean during the Cretaceous [5]. Rifting and graben formation probably began in Late Jurassic to Early Cretaceous times resulting in massive deposition of non-marine (thick sequence of continental grits and pebbly sands) facies. This sequence was, subsequently, and along with the basement floor, block-faulted in the Late Cretaceous producing a series of horsts and graben [5].



Fig 2: General Geological Framework of Dahomey Basin (After [3])

\subsection{Stratigraphy}

The lithostratigraphic units of the eastern margin of Dahomey basin is summarized in Fig 3. The oldest unit in Dahomey Basin is Abeokuta Group [6] which lies unconformably on the crystalline Basement Complex of South western Nigeria. It ranges from Lower Paleozoic to Pre-Cambrian age consisting of grits, sandstones, clay, thin bands of sandy limestone and shale. Ise (study area), Afowo and Araromi Formations belong to the Abeokuta group. The Ewekoro Formation, a shaly limestone unit conformably overlies the Araromi Formation [7]. It is highly fossiliferous and Paleocene in age. Akinbo formation, Paleocene-Eocene in age, overlies Ewekoro formation which consist of shale and clay sequence [8]. The Akinbo Formation is 8-9 metres thick at its type locality; the formation extends into the Republics of Benin and Togo.

Oshosun formation (Eocene in age), overlies Akinbo formation consisting of greenish-grey or beige clay and shale with interbedded sandstones [6]. Ilaro formation conformably overlain Oshosun formation, consisting of yellowish, massive, poorly consolidated cross-bedded sandstone[9]. It is Middle to Upper Eocene in age based on palynological studies [6]. Coastal Plain Sands makes up the youngest stratigraphic sequence in the eastern Dahomey basin, consisting of poorly sorted sands with lenses of clays [6]. The Coastal Plain Sands as well as The Recent Alluvium are considered to be the youngest unit in the eastern portion of the Dahomey basin of the Nigeria sector [5]. 


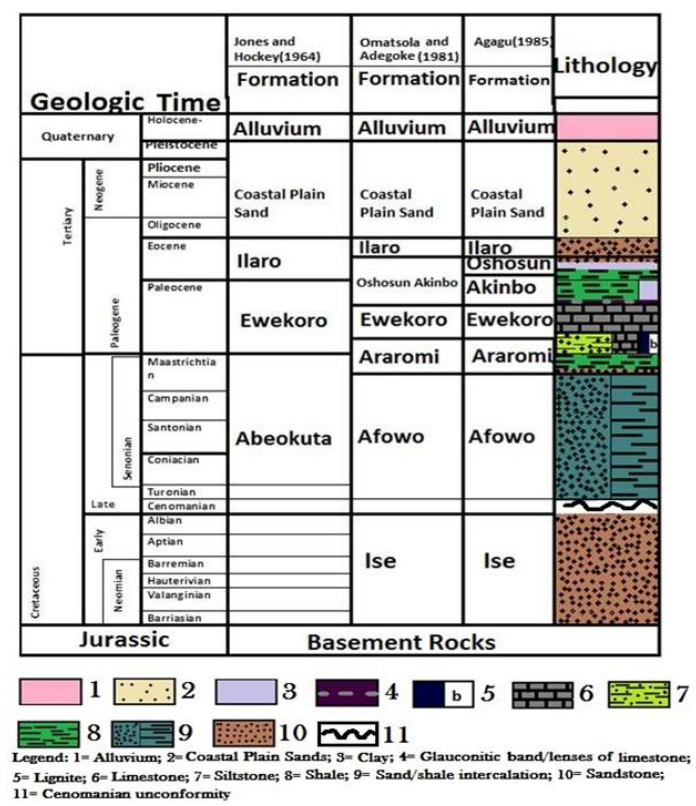

Fig 3: Stratigraphic unit of eastern Dahomey basin

\section{Methodology}

The methodology employed in this study involves both field and laboratory studies. The field analysis entails detailed observation and recording of sedimentary features such as thickness, grain size, texture, colour, sedimentary structures within the localities of Idagolu, Orita J4 and Iwopin. Twenty (20) sandstone samples were collected during the field exercise. All these samples were subjected to laboratory analyses. Thin sections from the sandstone samples were impregnated with blue dye to enhance porosity identification and viewed under petrologic microscope at the Geological laboratory of the University of Lagos. Thin section analysis assist in identifying various mineral compositions and estimate modal percentages of the studied sandstone. Dry sieving method was also employed for granulometric analysis, where textural parameters such as mean, sorting, skewness and kurtosis for each sample were calculated from the curves.

\subsection{Lithologic Description}

\section{Results And Discussion}

The base of exposed section at Idagolu consists of gritty sandstone facies, which is about $7 \mathrm{~m}$ thick and overlain by kaolinite. The section consists of three finning upward cycles and each cycle begins with conglomeratic sandstone which grades into coarse to medium to fine grained sandstones (Fig 4). The sandstones which range from medium grained to pebbly sandstone are poorly to moderately sorted, friable and quartz arenitic. The medium to coarse grained sandstones of average thickness of $2 \mathrm{~m}$ are commonly planar cross bedded and bioturbated (Fig 5a). At Orita J4, the Ise Formation is about $2 \mathrm{~m}$ thick and consists of three sandstone beds that exhibit a repetitive cycles of coarsening and fining upward sequences. At the base, the sequence exhibits coarsening upward to a depth of about $0.8 \mathrm{~m}$ and then finning upward sequence alternating to the top of the section. The entire section lacks bioturbation by organisms and sedimentary structures (Fig 5b). Rock types identified include conglomerates that are reddish in colour and very angular clasts of mineral feldspars and quartz. The geologic unit grades into less coarse sands from the top to bottom of the exposure.



Figure 4: Idagolo lithologic section. Take note of the brownish to yellowish colours (arrow) caused by iron oxide stains, suggesting anoxic environment. Also, note the upward fining sequence, indicating a fluvial depositional environment 


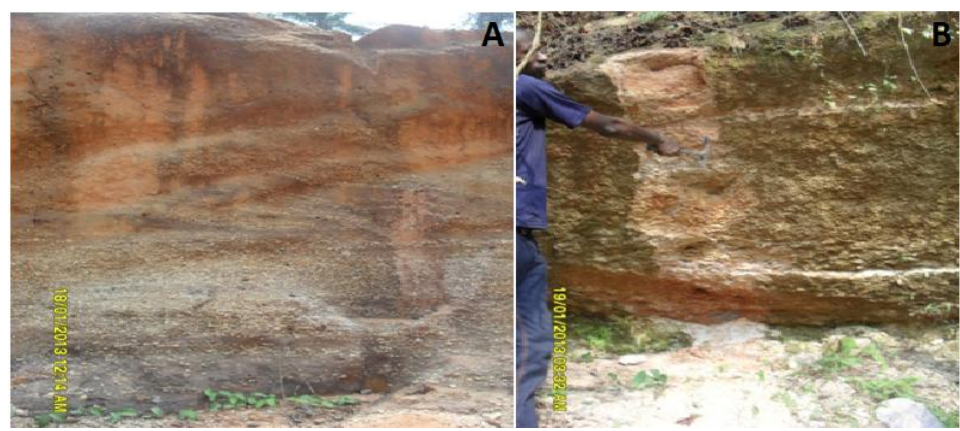

Figure 5: Idagolo lithogical section (arrow), and Orita J4 lithological section . Take note of the planar crossbed in Idagolo section, and the overall fining upward sequence of the two stratigraphic sections.

Table 1 summarise the grain size results performed on twenty (20) field samples obtained from parts of the Ise Formation, as exposed at Idagolu, Orita J4 and Iwopin along Abigi expressway and the corresponding interpretation. The graphs representing the results for the determination of relevant sedimentological parameters such as mean, standard deviation (sorting), skewness and kurtosis are shown in Fig 5.

Table 1 Grain size Results

\begin{tabular}{|c|c|c|c|c|c|c|c|c|}
\hline \multirow{2}{*}{$\begin{array}{l}\text { Sample } \\
\text { No }\end{array}$} & \multicolumn{2}{|c|}{ Grain size (Mean) } & \multicolumn{2}{|c|}{ Sorting (Standard Deviation) } & \multicolumn{2}{|c|}{ Skewness } & \multicolumn{2}{|c|}{ Kurtosis } \\
\hline & Result & Interpretation & Result & Interpretation & Result & Interpretation & Result & Interpretation \\
\hline IDG-2 & 1.88 & Medium sand & 0.53 & Moderately well sorted & -0.08 & $\begin{array}{l}\text { Near } \\
\text { symmetrical }\end{array}$ & 1.26 & Leptokurtic \\
\hline IDG-3 & 0.50 & Coarse sand & 0.75 & Moderately sorted & 1.00 & Fine Skewed & 1.46 & Leptokurtic \\
\hline IDG- 4 & 0.53 & Coarse sand & 0.76 & Moderately sorted & 1.00 & Fine Skewed & 1.00 & Mesokurtic \\
\hline IDG- 5 & 0.57 & Coarse sand & 0.88 & Moderately sorted & 1.20 & $\begin{array}{l}\text { Strongly } \\
\text { Skewed }\end{array}$ & 1.37 & Leptokurtic \\
\hline IDG-6 & 0.60 & Coarse sand & 1.64 & Poorly Sorted & 0.14 & Fine Skewed & 1.00 & Mesokurtic \\
\hline IDG-7 & 0.63 & Coarse sand & 0.29 & Very well sorted & -2.61 & Coarse skewed & 1.28 & Leptokurtic \\
\hline OJ4- 3 & -0.47 & $\begin{array}{ll}\text { Very } & \text { Coarse } \\
\text { Sand } & \end{array}$ & 1.77 & Poorly Sorted & 2.35 & $\begin{array}{l}\text { Strongly } \\
\text { Skewed }\end{array}$ & 0.88 & Platykurtic \\
\hline O J4- 4 & 0.33 & Coarse sand & 0.66 & Moderately sorted & 1.10 & Fine Skewed & -3.68 & $\begin{array}{l}\text { Very } \\
\text { Platykurtic }\end{array}$ \\
\hline OJ4- 5 & 0.40 & Coarse Sand & 0.69 & Moderately sorted & 1.39 & $\begin{array}{ll}\text { Strongly } & \text { Fine } \\
\text { Skewed } & \end{array}$ & 1.64 & $\begin{array}{l}\text { Very } \\
\text { Leptokurtic }\end{array}$ \\
\hline O J4- 6 & 0.53 & Coarse sand & 0.76 & Moderately sorted & 0.43 & $\begin{array}{l}\text { Strongly fine } \\
\text { skewed }\end{array}$ & 0.90 & Platykurtic \\
\hline OJ4- 7 & -0.33 & $\begin{array}{ll}\text { Very } & \text { Coarse } \\
\text { Sand } & \end{array}$ & 0.16 & Very well sorted & 1.00 & Fine Skewed & 1.11 & Leptokurtic \\
\hline O J4-8 & 0.03 & Coarse sand & 1.00 & Moderately sorted & 0.77 & $\begin{array}{ll}\begin{array}{l}\text { Strongly } \\
\text { skewed }\end{array} & \text { fine } \\
\end{array}$ & 1.02 & Mesokurtic \\
\hline IWP-2 & 0.77 & Coarse sand & 0.55 & Moderately well sorted & -0.24 & Coarse skewed & 0.69 & Platykurtic \\
\hline IWP-3 & 0.067 & Coarse sand & 0.55 & Moderately well sorted & 2.35 & $\begin{array}{ll}\text { Strongly } & \text { Fine } \\
\text { Skewed } & \\
\end{array}$ & 2.73 & $\begin{array}{l}\text { Very } \\
\text { Leptokurtic }\end{array}$ \\
\hline IWP-4 & 0.90 & Coarse sand & 1.45 & Poorly Sorted & 0.05 & Fine Skewed & 1.11 & Leptokurtic \\
\hline IWP-5 & 0.47 & Coarse sand & 0.73 & Moderately sorted & 1.00 & Fine Skewed & 1.46 & Leptokurtic \\
\hline IWP-6 & 0.23 & Coarse sand & 1.26 & Poorly Sorted & 0.39 & $\begin{array}{l}\text { Strongly fine } \\
\text { skewed }\end{array}$ & 1.15 & Leptokurtic \\
\hline IWP-7 & 0.67 & Coarse sand & 1.28 & Poorly Sorted & 0.23 & Fine Skewed & 1.42 & Leptokurtic \\
\hline IWP-8 & -0.27 & $\begin{array}{l}\text { Very } \text { Coarse } \\
\text { Sand }\end{array}$ & 0.22 & Very well sorted & -0.50 & Coarse skewed & -0.034 & $\begin{array}{l}\text { Very } \\
\text { Platykurtic }\end{array}$ \\
\hline IWP-9 & 0.63 & Coarse sand & 0.53 & Moderately well sorted & -0.20 & Coarse skewed & 1.20 & Leptokurtic \\
\hline
\end{tabular}
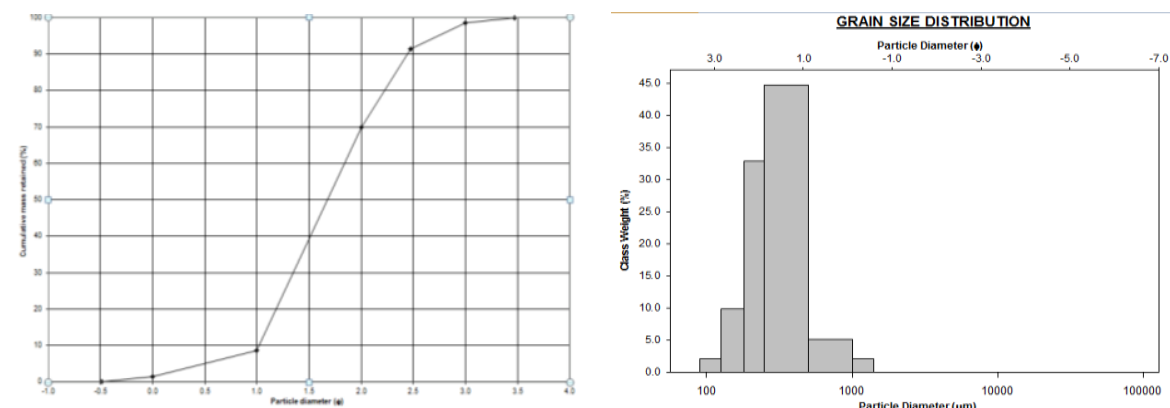

IDG 2 



IDG 3


IDG 6
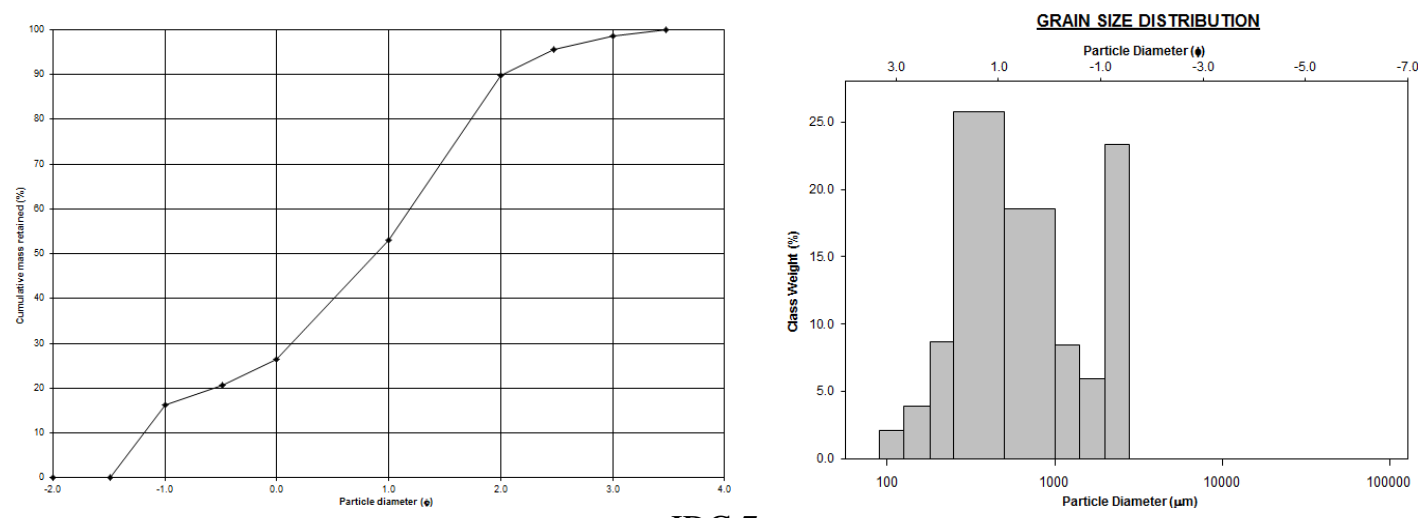

IDG 7

Fig 5: Graphical presentation of sieve analysis results of some samples from various locations: Idagolu, Orita J4 and Iwopin

\subsection{Mineralogy}

The studied sandstones consist predominantly of abundance quartz grains which occupy average of $90 \%$. It is the main framework mineral. Other minerals include feldspar with average content of less than 5\%, mica (average 1\%), rock fragment (average less than 5\%), and heavy mineral $(<1 \%$ ). The mineral types identified were: monocrystalline quartz, polycrystalline quartz, K-feldspar, plagioclase feldspar, mica, rock fragments and heavy minerals. Most of the quartz grains are monocrystalline, while small amount of polycrystalline quartz grains were identified (Plate 1). The feldspar content recognised from the analysed sandstone samples is generally low (about 5\%) of the entire grain framework and are mainly plagioclase feldspar with minor K-feldspar (plate 2). Mica present includes muscovite (Plate 3) mainly with minor biotite (Plate 4). The content of these minerals averages about $1 \%$ in every analysed sample. Rock fragments are detrital particles mainly igneous fragments, metamorphic clasts and sedimentary fragments which are texturally immature to submature. 

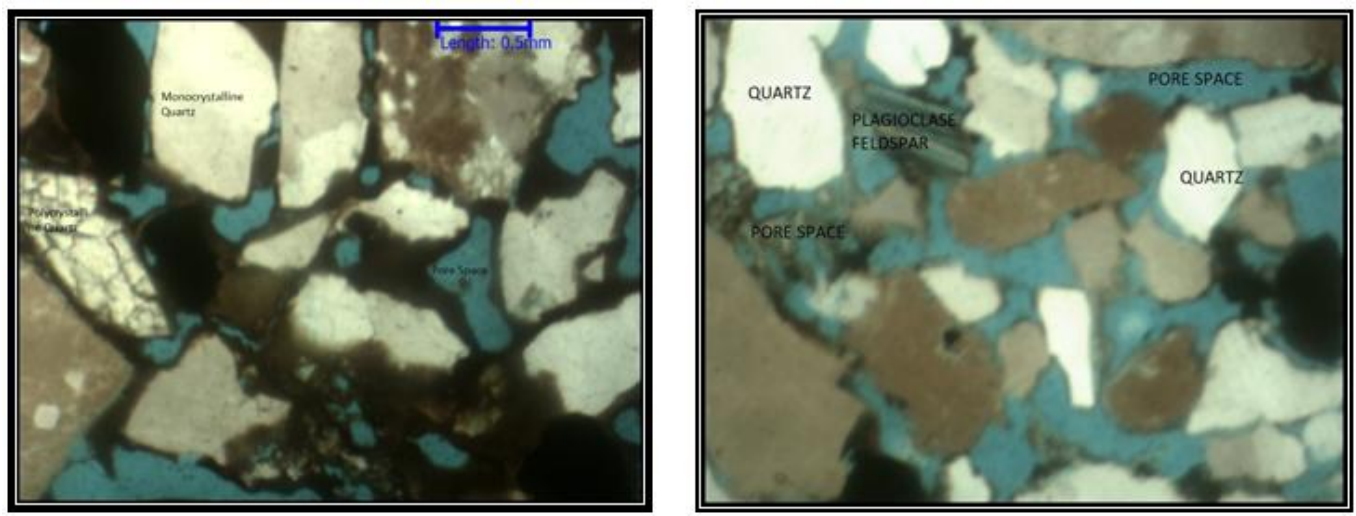

Plate 1: Photomicrograph showing monocrytalline and polycrystalline quartz,

(blue colour indicates pore space).

Plate2: Photomicrgraph showing plagioclase feldspar grain, quartz grains and pore spaces
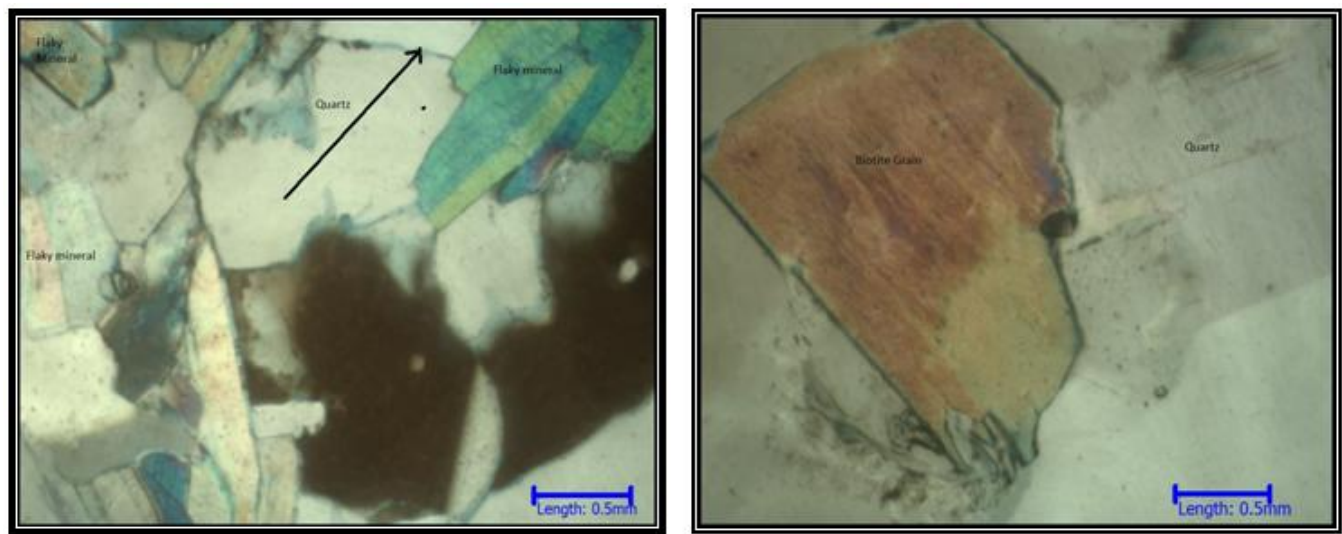

Plate3: Photomicrgraph showing flaky mineral grains (muscovite); Plate4:Photomicrgraph showing biotite mineral grain

\subsection{Degree of Roundness}

Grain roundness is a measure of the sharpness of the edges or corners of the sediment. Changes in roundness that occur by abrasion during sediment transport or solution; or cementation that takes place during diagenesis can influence surface texture by creating new grain surfaces [10]. Therefore, the degree of roundness of sediment grain is the extent to which grains attain roundness and sphericity during sediment transport.

Field sedimentological and petrographic studies reveal that the analysed sandstones of the Ise Formation are mainly angular to subrounded grains. The grain morphology shows low to high sphericity. This indicates that the sediments have travelled relatively short distance from the provenance. Hence, they are texturally immature to submature.

\subsection{Transportation History}

The degree of rounding is a reflection of the transportation history of the sediment. The grain size analysis results were used to deduce the transport history of the analysed sandstone samples of the Ise Formation. Three main sediment size types are present; very coarse, coarse and medium grain. The very coarse to coarse conglomeratic sand observed were deposited with high energy conditions in which smaller grains were transported away leaving the heavier sediments. On the other hand, the medium grained sediments are suggested to have been transported further down the river channel at relatively lower energy. Also, the coarse to very coarse are mainly poorly sorted sediment which has been deposited by high energy of transportation. This high energy did not allow selective sorting of the sediment.

\subsection{Petrography and Classification}

Quartz grains represent more than $90 \%$ of the entire framework; they are mostly monocrystalline and very few polycrystalline types are present. Feldspar content (less than 5\%) is generally low. Lithic grains and micas are rare. Classifying these compositions based on three end members of Quartz (Q), Feldspar (F) and Rock fragment (R) and on [11]scheme, the studies sandstones (Ise Sandstone Formation) is mainly quartz arenites with few samples known to be quartz wacke. 


\subsection{Depositional Environment}

Two distinct facies models are possible within the fluvial systems: a gravelly facies associated with alluvial fans and braided rivers facies; and sandy facies associated with meandering systems (Sengupta, 2011). The facies characterising fans and braided deposits in the study area are the clast-supported, commonly imbricate gravel with poorly defined sub horizontal bedding, planar cross bedding gravel, transitional, from clast-supported gravel through matrix supported conglomeratic sand. The facies of the meandering systems are exhibited with fining upward sequences preserved in point bars sub environment [12]. Therefore, the sandstone sediments of the Ise Formation were deposited in alluvial, braided stream and meandering systems. The fining upward sequences at Idagolu and Orita J4 are indicative of meandering systems within the point bar sub environment while the coarsening upward pattern at Idagolu is reflective of the beach environment, a shallow marine environment.

\section{Conclusion}

Granulometric and petrographic examination of thin section analyses of the studied sediments revealed that framework- grain size ranges from medium grained to pebbly sand. The sizes of the framework grains tend to decrease upward the stratigraphic sections. This was probably due to fluctuation in the energy of deposition as well as decrease in the energy of deposition as movement continued to the distal portion of the basin. Framework-grains were predominantly poorly sorted, angular with low sphericity which suggests deposition close to provenance and of short transport distance in a fluvial dominated setting. This is further revealed by a bivariate plot of graphic skewness versus graphic standard deviation, which indicates further that the sandstones were deposited by fluvial process. Petrographic examination of thin section revealed quartz as the dominant mineral, with a very high average percentage of $90 \%$, while feldspar minerals were of low percentage $(2.09 \%$ average).

\section{References}

[1]. Bjørlykke, K., 2015, introduction to sedimentology, petroleum geoscience, Springer, p. 31-90.

[2]. Burke, K., Dessauvagie, T., and Whiteman, A., 1971, Opening of the Gulf of Guinea and geological history of the Benue Depression and Niger Delta: Nature, v. 233, no. 38, p. 51-55.

[3]. Billmann, H., 1976, Offshore stratigraphy and paleontology of the Dahomey Embayment: Proceedings 7th African Micropaleontological Colloqium, Ile-Ife, Nigeria

[4]. De Klasz, I., 1978, The west African sedimentary basins: The Phanerozoic geology of the world. The Mesozoic: Elsevier, Amsterdam, p. 371-399.

[5]. Omatsola, M., and Adegoke, O., 1981, Tectonic evolution and Cretaceous stratigraphy of the Dahomey Basin: Journal of Mining and Geology, v. 18, no. 1, p. 130-137.

[6]. Jones, H. A., and Hockey, R., 1964, The Geology of Part of South-western Nigeria: Explanation of 1: 250, Ooo Sheets Nos. 59 and 68, Geological Survey of Nigeria.

[7]. Adegoke, O. S., 1977, Stratigraphy and paleontology of the Ewekoro Formation (Paleocene) of southwestern Nigeria. Nig. Bull. Am. Palaeontol., Vol. 71, No. 295, 357pp

[8]. Ogbe, F., 1972, Stratigraphy of strata exposed in the Ewekoro quarry, Western Nigeria: African geology, p. 205-322.

[9]. Nton, M., Ikhane, P., and Tijani, M., 2009, Aspect of Rock-Eval Studies of Maastrichtian-Eocene sediments from subsurface in the eastern Dahomey Basin, southeastern Nigeria: European Journal of Scientific Reasearch, v. 25, no. 3, p. 417-427.

[10]. Holomuzki, J. R., and Biggs, B. J., 2003, Sediment texture mediates high-flow effects on lotic macroinvertebrates: Journal of the North American Benthological Society, v. 22, no. 4, p. 542-553.

[11]. Pettijohn, F., J., Potter, P., E., \& Siever, R., 1972. sand and sandstones, Springer-Verlag, New York-Heidelberg-Berlin.

[12]. Sengupta, S. M., 2011, introduction to sedimentology CBS Publishers p. 163-170. 